DOI https://doi.org/10.30525/978-9934-588-80-8-2.42

\title{
КОУЧИНГОВИЙ ПІДХІД ПІД ЧАС ЗДІЙСНЕННЯ ПРОФЕСІЙНОЇ ДІЯЛЬНОСТІ СУЧАСНОГО ВИКЛАДАЧА ВИЩОЇ ШКОЛИ
}

\author{
Нежинська О. О. \\ кандидат психологічних наук, дочент, \\ доиент кафедри психології \\ Інститут підготовки кадрів державної служби зайнятості Украӥни \\ м. Київ, Украӥна
}

Метою роботи $є$ висвітлення особливостей застосування коучингового підходу під час здійснення професійної діяльності сучасного викладача вищої школи, оскільки в умовах інновацій, трансформацій та в цілому модернізації системи вищої освіти як в Україні, так і країнах Свропейського Союзу, важливе місце займає здатність викладача відповідати цим вимогам та швидко реагувати на відповідні зміни, орієнтуватися у цих складних процесах тощо. Тому використання коучингового підходу під час викладання є сьогодні одним з ефективних методів викладача вищої школи при розробці технології навчання й організації навчального процесу. Підтримувати, допомагати, ставити завдання та бути поруч під час їх вирішення, «іти рука об руку» разом із студентом, дбати про духовні цінності, а також тримати фокус уваги на вирішенні проблеми, бути доступним, відкритим і професійним $\epsilon$ умовою забезпечення професійного й особистісного зростання майбутніх фахівців під час навчальновиховного процесу у закладі освіти.

Ще приблизно 2500 років тому давньогрецький філософ Сократ під час навчання своїх учнів використовував підхід, який передбачав задавання питань. Відповідно саме завдяки сформульованим питанням він таким чином сприяв тому, щоб учні самі знаходили відповіді або їх різні варіанти, як саме поліпшити власне життя. У цьому контексті передбачалося досягнення вчителем декількох цілей: по-перше, за допомогою питань діагностувався інтелектуальний потенціал учня, подруге, здійснювалися допомога та супровід щодо самостійного досягнення учнем мети, по-третє, надавалися завдання для самостійного їх опрацювання та вирішення.

Сучасні дослідники та практики висвітлюють особливості коучингового підходу в різних сферах життєдіяльності людини, і на сьогоднішній день існують різноманітні погляди щодо поняття 
«коучинг», але це не змінює його суті. Так, спираючись на одного із засновників коучингу, Тімоті Голлві [2; 5], зазначимо, що коучинг - це методика розкриття потенціалу особистості для максимізації власної продуктивності та ефективності. Це сучасна технологія, яка дозволяє якісно та швидко визначити проблеми та шляхи їх вирішення, це допомога у розкритті власного потенціалу особистості, застосування якої $є$ дуже важливим саме у діяльності викладача вищої школи. Інший коуч, Майлз Дауні [1], визначає коучинг як мистецтво сприяти підвищенню результативності, навчанню та розвитку іншої людини. Польська тренерка та коуч Анна Цивінська [4] дає визначення коучингу як процесу підтримки розвитку та закріплення умінь за допомогою другої особи (коуча) через спостереження, постановку цілей і завдань, регулярне надання зворотного зв'язку та тренування нових моделей поведінки. На наш погляд (Олена Нежинська, Володимир Тименко), коучинг - це допомога у розкриті потенціалу клієнта, використання ним власних ресурсів та можливостей для досягнення максимального результату, шанс виявити все найкраще, що $є$ в його особистості, i, на основі цього, це поштовх до розвитку [3].

Слід зазначити, що зараз у системі вищої освіти викладач виконує різноманітні функції наставника, аналітика, дослідника, консультанта, фасилітатора і т.ін. Саме тому коучинговий підхід, для якого характерними ознаками $\epsilon$ роз'яснення, уточнення, підтримка, заохочення, планування нових шляхів і дій, $\epsilon$ універсальним засобом у процесі щоденної міжособистісної комунікації викладача та студента, під час якого формуються навички поведінки у критичних ситуаціях, відбувається розвиток професійної гнучкості та мобільності, розширюються рамки свідомості, відпрацьовуються вміння розглядати проблемне питання під різними кутами зору, закріплюються звички різновекторного планування конкретних дій i, відповідно, збагачення власної діяльності новими варіантами та засобами їх виконання. Коучинговий підхід у діяльності викладача дозволяє ефективно працювати на суб'єкт-суб'єктному рівні, допомагати іншим у розкритті та розвитку особистісного потенціалу, підвищенні особистої ефективності, побудові конструктивних відносини зо всіма учасниками освітнього процесу, які в свою чергу максимально ефективно працюють на результат вирішення актуальних завдань освітнього закладу та його розвитку загалом.

У процесі здійснення професійної діяльності викладачу, як уже було відмічено, у рамках коучингового підходу варто задавати студенту відкриті запитання i уникати закритих, оскільки сьогодні старі традиційні моделі передачі інформації викладач-студент завдяки лекційним формам уже у минулому. Потрібно створювати освітній діалог, а відкриті питання допоможуть це зробити, тому що у цьому 162 
випадку вони формують простір до розгорнутої й обгрунтованої відповіді, дискусії, навчають i дозволяють мислити креативно, рефлексивно, критично тощо, тим самим виводячи на новий рівень міжособистісної взаємодії взаємини викладача і студента на основі зацікавленості, співдії та співпраці [6]. Також це і фактичні питання, конвергентні та дивергентні, оціночні та перевірочні питання і т.ін. У цьому контексті можуть допомогти і коучингові інструменти, такі як модель GROW (T-GROW), стратегія Уолта Діснея, модель OSCAR, «Колесо життя» і т.ін., які власне і складаються із питань, на які потрібно відповісти [3; 7].

Разом із цим, необхідним $є$ відмітити, що використовувати коучинговий підхід може викладач, який володіє відповідними компетенціями, демонструє емпатію, цікаву поведінку та стиль спілкування, «пірнає» в глибину проблеми або ситуації, зацікавлений предметом (дисципліною) i співрозмовником, мотивує та спонукає студента до пошуку відповідей і рішень, вчить навчатися, допомагає вибудовувати логічні та причинно-наслідкові зв'язки, стимулює до більш глибокого аналізу будь-якого питання, надихає до створення власної траєкторії розвитку тощо. Так, за стандартами Міжнародної Федерації Коучингу (International Coach Federation - ICF) існує одинадцять ключових професійних компетенцій коуча [3], які згруповані у чотири блоки (або логічні групи): 1) створення фундаменту (відповідність етичним нормам i професійним стандартам); 2) спільне створення відносин (встановлення довірливих взаємовідносин, допомога, підтримка, супровід); 3) ефективна комунікація (активне слухання, зацікавленість, пряма комунікація, сильні питання); 4) фасилітація навчання та результатів (стимулювання усвідомлення, планування та постановка цілей, проектування дій, управління прогресом і відповідальністю).

Сучасний заклад вищої освіти $є$ центром передачі компетенцій студентові, а коучинговий підхід дозволяє створити таке середовище, в якому можливе розкриття внутрішнього потенціалу студента у процесі творення майбутнього фахівця-професіонала відповідного освітнього напряму. Тому під час міжособистісної взаємодії викладача і студента відбувається набуття навичок студентом щодо конструктивної комунікації, ведення плідних переговорів, попередження конфліктних ситуацій, а також розвиток вміння керувати собою, своїм станом, своїми ресурсами, визначення власних цілей та ресурсів, розвиток мотивації, вихід із «зони комфорту» і т.ін. Разом 3 цим варто підкреслити, що єдиний шлях до кращого результату можливий тільки через постійну роботу над собою щоденно, формування впевненості на шляху поставленій меті, максимально швидкому просуванні до іiі реалізації засобами мобілізації внутрішнього потенціалу, вірі в себе, освоєнню передових стратегій досягнення результату, формування, розвитку й 
удосконалення необхідних для цього умінь і навичок, відповідних компетенцій. Це створює умови для формування професійної компетентності майбутнього фахівця, здатного до реалізації своїх потенційних можливостей, веде до розвитку студента, самостійного прийняття у подальшому відповідальних рішень у різних ситуаціях життєвого вибору, прогнозуючи їх можливі наслідки, а також побудови власного майбутнього, самовдосконалення особистості в цілому.

Отже, в сучасних умовах модернізації освіти використання коучингового підходу під час здійснення професійної діяльності сучасного викладача вищої школи сприятиме розвитку особистості студента, формуванню у нього відповідних фахових компетенцій, самореалізації та самовдосконаленню, творенню майбутнього фахівцяпрофесіонала, а також забезпечення зростання якості освіти в рамках євроінтеграційних процесів загалом.

\section{Література:}

1. Дауни М. Эффективный коучинг: Уроки коуча коучей (Effective Coaching: Lessons from the Coaches' Coach) ; пер. с англ. Е. Гладкова. Москва : Издательство «Добрая книга», 2013. 288 с.

2. Нежинська О. О., Тименко В. М. Коучинг як технологія формування професійної компетентності освітянина : Збірник тез доповідей Всеукр. наук.-практ. конф. «Сучасні тенденції розвитку науки і освіти в умовах поглиблення євроінтеграційних процесів», Мукачево, 17-18 трав. 2017 р.) ; Ред. кол.: Т. Д. Щербан (гол. ред.) та ін. Мукачево : Вид-во МДУ, 2017. С. 194-196.

3. Нежинська О. О., Тименко В. М. Основи коучингу: навч. посібник. Київ ; Харків : ТОВ «ДІСА ПЛЮС», 2017. 220 с. : іл.

4. Cywińska Anna, Majewska Sylwia, Pępiak-Kowalska Kamila, Szwec Eliza Coaching. Wydanie pierwsze. Lublin, 2013. $190 \mathrm{s.}$

5. Gallwey, W. Timothy The Inner Game of Tennis. 1st. New York : Random House, 1974. 141 p.

6. Nieżyńska Helena, Tymenko Wołodymyr Coaching jak innowacyjna technologia pedagogicznego współdziałania w systemie wyższej edukacji Ukrainy : Pracy IV Międzynarodowej Multidyscyplinarnej Konferencji Naukowej «Dylematy współczesnej edukacji. Formy i metody pracy z uczniem ze specjalnymi potrzebami edukacyjnymi», WSL, Częstochowa, Polska, 12 lipca 2016 r. Problemy nowoczesnej edukacji ; Pod red. Edyty Sadowskiej, Wieslawa Sztumskiego. Częstochowa : WSL, 2016. T. VI. S. 139-146.

7. Stoltzfus T. Sztuka zadawania pytań w coachingu. Wyd. Aetos Media. Wrocław, 2012. $102 \mathrm{~s}$. 